\title{
POLISH CONTRIBUTORS TO THE MODERN TURKISH STATE
}

\section{Karolina Wanda Olszowska}

Jagiellonian University in Kraków
http://orcid.org/0000-0003-0535-912X

\begin{abstract}
Poles have found a place of refuge in Turkey (the Ottoman Empire) for centuries. For example, there is a village near Istanbul, Polonezköy (former Adampol), which was especially created with the Poles on the search for a second home in mind. When one considers the Polish community in Turkey during and after the Second World War, the contributions made by the Polish engineers to the development and expansion of the Turkish aviation and industry are often forgotten. The assistance that Turkey provided Poles with during the war as a 'friendly' neutral country has also been overlooked. Although, there were relatively few Poles living in Turkey during this period, they played a vital role in the development of the country. Nowadays they barely receive a mention. For the most part, their accomplishments have been overlooked. The aim of this paper is to draw attention to the shared past and to the period when these two countries came to each other's assistance once more.
\end{abstract}

Keywords: Turkey, Polish contributors, the Second World War, IRO.

There are numerous interesting examples of Poles who contributed to the construction of Turkish railways and telegraph system, the exploitation of coal deposits in Zonguldak, and to the development of various branches of modern industry in Turkey. Yet almost none of these figures has been honoured by a monument or even a commemorative plaque in Turkey. No schools or streets bear their names. Nor are they mentioned in academic or school textbooks. ${ }^{1}$ They also remain largely anonymous in Poland. This is a pity because their legacy could help build bridges between these two countries.

In the present article I intend to focus exclusively on the topic of Poles in Turkey during the Second World War and the immediate post-war years up until Turkey's

1 E.g. Ortaöğretim Tarih Ders Kitabl, MEB Yayınları, İstanbul 2018; Ortä̈ğretim Tarih Ders Kitabı, Tuna Yayınları, İstanbul 2019. 
entry into NATO. I have chosen this period, because the timeframe encompassed by the Ottoman Empire (in the context of Poles in Turkey) has already been much better explored. In 1952, Turkey joined NATO and thus opted to join the West, which altered the situation of Poles in Turkey and deserves to be a separate topic of research. The most important question posed in this text is whether Poles constituted a unique group in Turkey and how they influenced the development of this country.

\section{POLES IN THE OTTOMAN EMPIRE}

The beginning of Polish-Ottoman relations officially dates back to 1414, when the first Polish legate was sent to the Ottoman Empire. ${ }^{2}$ At that time Dragomans were important figures. One of the best-known Dragomans of Polish origin was Wojciech Bobowski, ${ }^{3}$ known also as Ali Ufka. He was a veritable Renaissance man. Besides being a Dragoman, he was also a musician, composer and creator of the first anthology of Turkish-Ottoman music. ${ }^{4}$ He learned the rules of the Turkish-Ottoman music and how to play Ottoman instruments. He was soon elevated to the position of conductor in the palace and later was also employed as a teacher, thanks to his knowledge of musical notation. ${ }^{5} \mathrm{He}$ was a polyglot, with knowledge of around 15 languages. He was the author of a Latin-Turkish dictionary, a Turkish grammar and a TurkishFrench phrasebook. ${ }^{6} \mathrm{He}$ is also known as a translator of the Bible (the Old and New Testaments and the Apocrypha). ${ }^{7}$

One specific symbol of the Polish presence in the Ottoman Empire is the aforementioned Polonezköy. Michał Czajkowski ${ }^{8}$ (better known as Mehmet Sadık Paşa), a representative of the Hôtel Lambert faction in the Ottoman Empire, decided to lease some forest land near Istanbul from Lazarist Priests and turn it into a specially designated site for Polish refugees residing in Turkey. The Poles signed the lease agreement for the land on March 3, 1842. ${ }^{9}$ However, the first immigrants only settled there fourteen years later. In 1883 Prince Adam Jerzy Czartoryski ${ }^{10}$ purchased the property

2 D. Kołodziejczyk, "Komşuluktan Kardeşliğe: Osmanl1-Polonya ve Türkiye-Polonya Tarihi İlişkilerinden Birkaç Manzara" [in:] 600. Yılında Türkiye-Polonya İlişkileri Sempozyumu Bildirileri, ed. H. Topaktaş, Ankara 2014, p. 38.

3 Wojciech Bobowski - b. 1610 Lwów, d. 1675 İstanbul.

4 A. Ufki, Мeстиа-i Saz ü Söz, İstanbul 1650.

5 The exact dates when Ali Ufke was in the palace are unknown, most likely he came to the Ottoman Empire in 1633-1634 and left the palace in 1652.

6 Türkçe-Latince Sözlük, İstanbul 1658; Grammatica Turcia-Latina, İstanbul 1658.

A. Pawlina, "Wojciech Bobowski (Ali Ufki) - Polak na osmańskim dworze" [in:] Wschód muzulmański $w$ ujęciu interdyscyplinarnym. Ludzie - teksty - historia, eds. G. Czerwiński, A. Konopacki, Białystok 2017, pp. 154-162.

8 Michał Czajkowski - b. 1804 Halczyniec (Russian Empire), d. 1886 Borki (Russian Empire).

9 H. Topaktaş, "Polonezköy (Adampol) 1842-1922 - Kurulus, Tabiyet Meselesi, İmar Faaliyetleri ve Sosyal Hayat," Belleten 2015, pp. 296-297.

10 Adam Jerzy Czartoryski - b. 1770 Warszawa, d. 1861 Montfermeil (France). 
from the Lazarist Priests. The inhabitants of the "Polish village" continued to own the croplands until the 1960s. If someone wanted to settle in Polonezköy, he had to meet two conditions. Firstly, he had to be of Polish origin or at least of Slavic origin. Secondly, he had to be Roman Catholic. ${ }^{11}$

Poles living in Polonezköy during the Second World War were obliged to pay property tax (in Turkish: Varlık Vergisi). Muslims had to pay $1 / 8$ of the total value of their property, as well as foreigners, furthermore, Dönme 1/4 and non-Muslims 1/2. As a result, the fiscal burden fell particularly heavily on merchants from large cities and non-Muslims, who had to pay up to ten times higher amount than the Muslims. In total, it accounted for $55 \%$ of their total tax revenues. ${ }^{12}$ The residents of Polonezköy were taxed as non-Muslims, and thus had to pay large amounts of taxes, all the more, because this village was relatively wealthy. ${ }^{13}$

Another Pole who permanently inscribed himself into the history of the Ottoman Empire was Konstanty Borzęcki (Mustafa Celaleddin Paşa). ${ }^{14} \mathrm{He}$ became head of the Imperial Cartography Department and attained the rank of major-general. Mustafa Celaleddin wrote a book entitled The Turks Past and Present ${ }^{15}$ in which he employed ethnological and linguistic arguments to demonstrate racial unity between Turks and Europeans ${ }^{16}$ Mustafa Kemal ${ }^{17}$ was a reformist who was keen to purge the Turkish language of its Persian and Arabic loanwords, and to replace the Arab alphabet with Latin letters. In the margins of Mustafa Celaleddin's book, Mustafa Kemal wrote "to implement."."18

Alongside military figures, artists also occupy an important place in OttomanPolish history. Stanisław Chlebowski ${ }^{19}$ was a Polish painter and a renowned specialist in Oriental themes. In the years 1864-1876 Chlebowski was master painter for Sultan Abdülaziz (r. 1861-1876) and took up residence in Constantinople. The Sultan personally prepared sketches of the paintings that Chlebowski later painted.

Hence, Poles helped shape the Ottoman Empire in a wide variety of ways, earning respect, in particular for their military feats, but also for their contributions to art, music, law and language reform.

11 P. Ziółkowski, Adampol (Polonezkioj) Osada Polska w Azji Mniejszej - Zapiski historyczne, Poznań 1929, p. 22.

12 B. Lewis, Narodziny nowoczesnej Turcji, Warszawa 1972, p. 353.

13 K. Dopierała, Adampol - Polonezköy. Z dziejów Polaków z Turcji, Poznań 1983, pp. 130-131.

14 Konstanty Borzęcki - b. 1826, Modrzewiec, d. 1876 Novoselë (Albania).

15 M. Djelaleddine, Turcs Anciens et Modernes, Constantinople 1869.

16 A. Odabaş1, Mustafa Celaleddin Paşa ve Eski ve Yeni Türkler, İstanbul 2014, pp. 23-28.

17 Mustafa Kemal (Atatürk) - b. 1881 Salonica, d. 1938 İstanbul. Founder and the first President of the Republic of Turkey.

18 Ş. Turan, Atatürk'ün Düşünce Yapısını Etkileyen Olaylar, Düşünürler, Kitaplar, Ankara 1999, pp. 26-27.

19 Stanisław Chlebowski - b. 1835 Pokutyńce, d. 1884 Kowanówko. 


\section{POLES IN TURKEY DURING THE SECOND WORLD WAR}

A few days after Poland suffered its final defeat in the September Campaign in 1939, the Turkish government declared that it did not recognize any acts dismembering the Polish state during the war and considered the current situation as stemming from the temporary circumstances of war. Poland was thus still regarded as an independent state and, as it had done when Poland had previously been partitioned, Turkey refused to recognize this new division of the country. ${ }^{20}$ On September 17, 1939, the Bank of Poland's gold reserves, worth 330 million PLN in gold and weighing nearly 70 tons, arrived on a British ship in Istanbul's port.

On October 29, 1939, a military parade was organized in Ankara to celebrate Republic Day. The Polish diplomatic corps attended the event and received a warm ovation from those in attendance. ${ }^{21}$ In October 1939, the General Staff Headquarters in Ankara gave the evacuating Polish army permission to cross the Straits. Polish officers and non-commissioned officers were transported across Turkish territory, en route either to Beirut or the Pyrenees, but their families remained in Turkey. The Turkish government expressed its admiration for the heroism of the Polish army, but would not agree to the establishment of collection points for individual units from Romania for fear of provoking conflict with the USSR. ${ }^{22}$ In December 1939, 24 Polish engineers residing in Romania obtained employment in Turkey. ${ }^{23}$ After the occupation of Romania, the Polish embassy, together with the embassy's archives, were evacuated to Turkey. Ankara issued residence visas to Polish diplomats and their families without any problem. The idea was even raised of bringing either the "Pułaski" or the "Warszawianka" to the port of Istanbul and use these ships as accommodation for officers and non-commissioned officers, who at that time lived in hotels in Istanbul, in this way to reduce accommodation costs. Bulgaria's decision to close the border and the restrictions placed by Romania on the number of officers who could cross the sea into Turkish territory to $3-5$ officers per week posed a major problem. ${ }^{24}$ In spite of these, in November and December, a number of officers and non-commissioned officers, mainly pilots, arrived in the country. There were also 13 nurses and a curator from Wawel Castle who arrived with the Wawel collection, which he intended to take to France. ${ }^{25}$

On February 14, 1940, ship "Theophile-Gautier" together with 300 Polish officers and soldiers from Romania set out from Istanbul for Marseilles. In May 1940, the

20 M. Sokolnicki, Dziennik ankarski 1939-1943, Londyn 1965, vol. I, p. 70.

21 J.S. Łątka, Polacy w Turcji, Lublin 1980, p. 80.

22 The Polish Institute and Sikorski Museum in London [in the following: PISM, London], Staff of the Commander-in-Chief and the Ministry of Military Affairs, 1939-1948 [later: A.12.] / 60 / 1, Reports from Polish Embassy in Ankara to Polish Government-in-exile, October-December 1939, p. 1.

23 PISM, London, October 4, 1939.

24 PISM, London, October 16, 1939.

25 PISM, London, October 18-24, 1939. 
Minister of Foreign Affairs Şükrü Saraçoğlu ${ }^{26}$ agreed to allow 20,000 Polish military personnel coming from Hungary and Romania to pass through Turkish territory on their way to Syria. Turks facilitating the escape issued transit visas en mass, and even approved the visa-free transshipment of Polish soldiers arriving on Romanian ships in Istanbul's port. ${ }^{27}$ One interesting point to note is that the engineers and their families who came in 1940 received Turkish citizenship that very same year on the basis of Article 6 of Law No. 1312. ${ }^{28}$ According to documents preserved in the Turkish archives of the Republic, in July 1940 former Prime Minister Felicjan Sławoj Składkowski and former Minister of Justice Witold Grabowski also resided in Turkey. They received permission to bring their families from Romania. ${ }^{29}$ Not all visitors received Turkish citizenship so quickly. One example was Roman Çekoviç, ${ }^{30}$ who came to Turkey in 1943 at the latest. He worked at the Turkish bank Sümerbank. His work permit was extended several times and he was only granted citizenship in $1949 .{ }^{31}$

In 1940, Turkey gave permission for Professor Tadeusz Kowalski ${ }^{32}$ from Krakow to enter the country so that he could lecture in the Faculty of Literature of the University of Istanbul. ${ }^{33}$ The authorities of the Third Reich agreed to the trip and a travel plan for the professor and his family had already been arranged with a stopover in Vienna. Although Professor Kowalski was scheduled to lecture at the university in the new semester, he eventually abandoned his plans for fear of being called a traitor after the war. ${ }^{34}$

However, it should not be forgotten that the Turkish government, above all else, tried to protect its own interests and acted cautiously in situations where expressing sympathy for the Polish cause carried the risk of repercussions. During the Second World War, the Polish mission was treated with great kindness. Michał Sokolnicki, ${ }^{35}$ the Polish Ambassador in Ankara in 1936-1945, mentioned in his memoires ${ }^{36}$ that in

26 Şükrü Saraçoğlu - b. 1887 Ödemiş, 1953 İstanbul (The fifth Prime Minister of Turkey and the Turkish Minister of Foreign Affairs during the early stages of the Second World War).

27 K. Dopierała, Emigracja polska w Turcji w XIX i XX wieku, Lublin 1988, p. 286.

28 Başbakanlık Cumhuriyet Arşivi (later: BCA) 30.18.1.2 Decisions of the Council of Ministers, 1920

1975 (in the following: DCM)/93.118.19; T.C. Resmî Gazete, No 4704, January 6, 1941.

29 BCA. 30.18.1.2 DCM/92.76.9.

30 There is no more information known about him.

31 BCA. 30.18.1.2 DCM/121.93.2.

32 Tadeusz Kowalski - b. 1889 Châteauroux, d. 1948 Kraków. Polish orientalist (Turkologist, Arabist and Iranist); he was considered one of the most versatile Polish orientalists because of the scope of his research, including languages, literature, folklore and Turkish, Arabic and Persian history.

33 T.C. Başbakanlık Devlet Arşivleri Genel Müdürlüğü BCA 030180102931027 [in:] Yoldaki Elçi Osmanlıdan günümüze Türk-Leh iliş̧ileri / Poset w drodze. Stosunki turecko-polskie od czasów osmańskich do dnia dzisiejszego, İstanbul 2014, p. 415.

${ }_{34}$ M. Stachow ski, "Kowalski, Caferoğlu und die Universität Stambul," Türk Dilleri Araştırmaları 1998, no. 8, pp. 211-228.

35 Michał Sokolnicki - b. 1880 Kaszewy Kościelne, d. 1967 Ankara.

36 M. Sokolnicki, Dziennik ankarski 1939-1943, vol. I, Londyn 1965, M. Sokolnicki, Dziennik ankarski 1943-1946, vol. II, Londyn 1974. 
April 1943 the Turkish Foreign Minister, Numan Menemençoğlu ${ }^{37}$ revived the custom of holding grand dinners in Ankara Palace. Due to the peculiar circumstances of the war, these dinners were organized separately for representatives of the Allies and the Axis countries, the one common denominator they shared was the presence of the Turks and representatives of the diplomatic corps of neutral countries. Next, the ambassadors invited all guests to dinner with them. This pleasant duty was primarily performed by Sokolnicki, in his capacity as dean of the corps. During these banquets the Turkish national anthem was played followed by - to the surprise of all those who present in the hall - the Polish national anthem, the Mazurek Dąbrowskiego. ${ }^{38}$

Ambassador Sokolnicki reported that Polish politicians viewed this as an unusual expression of Turkish sympathy for Poland. The ambassador himself mentioned that such a gesture of kindness did not embrace representatives of the USSR and the US present at the banquet. ${ }^{39}$ However, it is important to remember that Ambassador Michał Sokolnicki often presented a subjective viewpoint of events in his memoires. The priority of invitation for the dinner was based on diplomatic protocol. The Turkish government was very cordial, but within certain limits that ensured it did not insult either side. In fact, in his reports to the government-in-exile the Polish ambassador stressed that, despite their great sympathy, the Turkish government would do nothing that might worsen its relationship with the USSR. ${ }^{40}$

On behalf of the London government, Ambassador Sokolnicki appealed to the Minister of Foreign Affairs, Numan Menemençoğlu, to exert his influence on the Romanian government and ensure the release of Poles interned on their territory. He was particularly keen to obtain asylum in Turkey for former foreign minister, Józef Beck. ${ }^{41}$ Menemençoğlu promised to try to intervene in this matter. Poles from $\mathrm{Bu}-$ charest only began to arrive in Istanbul after August 23, 1944, when Romanian King Michael (r. 1927-1930 and 1940-1947) broke off relations with the Axis countries. Two days later, Mrs. Beck came to Turkey with her daughter. Unfortunately, Józef Beck had fallen ill and died in a detention camp in Romania, on June 5.

During the war, a relatively large number of engineers came to Turkey to work in the aircraft industry or perform specialized tasks connected with aircraft engines. Poles played a pivotal role in the establishment of the Turkish Air Association Aircraft Factory. The factory, which was managed by Polish engineers in the years 1941-1946, produced Miles M.14 A aircraft, based on a British license as well as its own models. Due to the presence of Polish engineers, the Turks referred to the plants as "Polish." Jerzy Wędrychowski ${ }^{42}$ was a very important figure in this community.

37 Numan Menemençoğlu - b. 1893 Baghdad, d. 1958 Ankara. Minister of Foreign Affairs of Turkey 1942-1944.

38 M. Sokolnicki, Dziennik ankarski, vol. I, p. 489.

39 Ibidem.

40 PISM, London, Ministry of Foreign Affairs (later: A.11.E) / 189, Poland's relations with Turkey, Greece and Bulgaria.

41 Józef Beck - b. 1894 Warszawa, d. 1944 Stăneşti (Romania). Minister of Foreign Affairs of Poland 1932-1939.

42 Jerzy Wędrychowski - b. 1902 Warszawa, d. 1961 Dallas. 
In October 1940, he came to Ankara with the first group of 17 Polish engineers. Wędrychowski's intention was to gather specialists abroad and gain working experience so that after the war they could return to Poland and help reconstruct the domestic aviation industry. Wędrychowski had been invited by the Turkish government to work on this project due to previous collaboration between Turkey and Poland in this field. In the years 1941-1948 he was director of the Aircraft Factory of the Turkish Aviation Association (Türk Hava Kurumu THK) in Etimesğut. ${ }^{43}$

During the Second World War, the Red Crescent provided aid for refugees on Turkish territory. Via this organization, members of the Polish émigré community were also able to send parcels containing vital necessities to relatives in the occupied homeland. ${ }^{44}$ When we consider Turkish aid for refugees during and after the war, it should not be forgotten that Turkey's economic situation was poor at this time. According to a report by the Polish embassy in Ankara in May 1945, 17,000,000 people were living in the Turkey, $95 \%$ of whom were working as farmers. ${ }^{45}$

Turkey suffered from a shortage of qualified workers, engineers and technical staff; therefore, they were very eager to welcome people with appropriate skills and training. ${ }^{46}$ As early as December 1939, 24 Polish engineers relocated to Turkey from Romania. Despite the fact that they did not have Turkish visas, all the usual red tape required to gain employment was waived.

Turkey also tended to be used as a country of transit (e.g. for Jews heading to Palestine) rather than as a destination. Whether, and to what extent, the Turkish government allowed transit in specific cases depended on the political situation between Turkey and the Axis countries. When relations became tense and repercussions were feared, the opportunities for transit were restricted. To facilitate work, transit visas were sometimes issued separately and sometimes collectively for all transports. ${ }^{47}$ Turkish archives include surviving permits issued to the Polish government allowing six vehicles to make the journey from Belgrade to Istanbul and from there via Mersin to Palestine, where Polish Jews were located. The Turkish authorities did not even require lists of names. The permits were simply issued for the vehicles. ${ }^{48}$

\section{POLES UNDER IRO PROTECTION}

One very interesting issue in the context of the present article is the fate of Polish refugees in Turkey after the Second World War. In the first post-war years (1945-

43 O.F. Baş, "THK Uçak Fabrikası ve Polonyalıların Rolü,” Mühendis ve Makina 2014, no. 55, pp. $36-42$.

44 T.C. Başbakanlık Devlet Arşivleri Genel Müdürlüğü BCA 030180102931027, p. 413.

45 PISM, London, A.11.E / 506, Turkey - internal situation, May 29, 1945, p. 1.

46 PISM, London, A.11.E / 286, Economic situation of Persia, Turkey, Romania and Bulgaria, 1945.

47 T. Kodal, "Türk Arşiv Belgelerine Göre II. Dünya Savaşı (1939-1945) Yıllarında Türkiye Üzerinden Filistin'e Yahudi Göçleri,” Atatürk Üniversitesi Atatürk Dergisi 2007, no. 5, p. 142.

48 BCA. 30.18.1.2 DCM/93.108.9. 
1951), several international organizations, such as the United Nations Relief and Rehabilitation Administration (UNRRA), the Intergovernmental Committee on Refugees (IGCR) and the International Refugee Organization (IRO) operated on Turkish territory. ${ }^{49}$ IRO was the first international agency set up by the United Nations Organization. It was active between 1947 and $1952 . .^{50}$ The IRO operated on a relatively small scale in Turkey, but at the same time a relatively large number of Poles were under its protection.

Polish refugees continued to enter Turkey even after the war had ended. One could find in Turkish archives an important letter written by Włodzimierz Bączkowski, ${ }^{51}$ the president of the Association of War Invalids of the Polish Army in the Middle East, to Hasan Saka, ${ }^{52}$ Minister of Foreign Affairs, asking for shelter for Polish soldiers who did not want to return to the Soviet-ruled Poland. Minister Saka's reply has not survived, but it is known that a number of Polish soldiers intended to stay in Turkey permanently, but only as a stopover on their way to the "West."

In August 1945, the Turkish Government formally recognized the Polish Government in Warsaw, and ipso facto the Polish Embassy in Ankara and the Polish Consulate General in Istanbul (the Consul General was Witold Korsak ${ }^{54}$ ) ceased to exist. ${ }^{55}$ At the beginning of 1946 the Turkish Government was confronted with the need to deal with a group of Poles opposed to the new Warsaw regime, because the Warsaw Chargé D'affaires in Ankara, Romuald Buczyński, ${ }^{56}$ did not want to look after them. The Turkish Government informed London that employing and accommodating them was problematic and the British Foreign Office considered transferring these Polish refugees to Lebanon. ${ }^{57}$ The Polish Chargé D'affaires distributed relief to those refugees who signed a declaration of loyalty to the new regime and declared a desire to return to Poland. According to a report from October 1946, there were 1221 displaced persons registered as being under UNRRA's protection in Turkey at this time, including 105 Poles..$^{58}$

49 K. Olszowska, "The Protection Provided by International Refugee Organizations in Turkey in the Immediate Post-war Period," Zeszyty Naukowe Uniwersytetu Jagiellońskiego. Prace Historyczne 2019, no. 3, p. 607.

50 P. Sękowski, "Activity of the International Community in Europe after the Second World War within the Scope of the International Refugee Organization as a Model of the Aid Action towards Refugees," Securitologia 2017, no. 3.

51 Włodzimierz Bączkowski - b. 1905 Siberia, d. 2000 Washington, D.C.

52 Hasan Saka - b. 1885 Trabzon, d. 1960 İstanbul. Minister of Foreign Affairs (1944-1947), and Prime Minister of Turkey (1947-1949).

53 T.S. Birbudak, B. Akbaba, "II. Dünya Savaşı Yıllarında Türkiye'de Bulunan Polonyalılar," Ankara Üniversitesi Türk Inkılâp Tarihi Enstitüsü Atatürk Yolu Dergisi 2018, no. 62, p. 7 (the article gives the name J. Baczkowski, but most likely it is about captain Włodzimierz Bączkowski - K.W.O.).

54 Witold Korsak - b. 1897 Sewerynówka, d. 2003 New York. The Polish diplomat who during the Second World War had acted as Polish Consul General in Jerusalem, and later also in Beirut and Istanbul.

55 PISM, London, A.12. / 24, Telegraph for Mr. Buczyński, in May 1945, p. 8.

56 Romuald Buczyński - Chargé D’affaires in Ankara (January 1946-August 1946).

57 The National Archives in London (later: AN, London), Foreign Office - FO 371 (later: FO 371) / 56603, Reports with telegrams to London on the subject of Poles refugees in Turkey, February 3, 1946, p. 2.

58 AN, France, AJ 43/52, International Rescue and Relief Committee, Istanbul Branch Report on Activities during 1945/1946, [Istanbul], August 10, 1946, p. 2. 
According to a report from March 1947, there were 95 persons in Turkey whose living conditions were deemed desperate. The above-mentioned group of special cases included 3 Poles. ${ }^{59}$ Out of the 18 Poles whose living conditions were classified, 3 individuals - M. Ibrahim Rifat and two members of his family - were deemed to be in a critical situation..$^{60}$ One Pole who found himself on the above-mentioned critical list was Witold Korsak. Michał Sokolnicki sent requests to the government in London asking for financial support for him because of the very difficult financial situation in which he found himself. The IRO sought extra money for individuals in financial difficulty, including Poles at the British embassy. One interesting person on this list is Jerzy Cybulski ${ }^{61}$ an engineer who had been issued a work permit by the Turkish authorities on February 14, 1941 and who was employed at the Turkish Iron and Steel Industry. A person with the same description was known to have obtained Turkish citizenship in $1950 .{ }^{62}$ It is unclear if it was the same person, although it was not uncommon for names to get mixed up in the IRO.

On July 24, 1948, Turkey and Poland signed Commercial and Payments Agreements. ${ }^{63}$ These economic concords had no impact on the plight of Polish refugees in Turkey. According to a report from June 21, 1949, 5438 Polish refugees were registered in the Middle East, 330 of them lived in Turkey, 237 of whom were considered employable according to IRO criteria, 61 were deemed borderline cases, and 32 as unemployable, and treated as "hard core cases," i.e. people who, mainly due to disability or old age, were the most problematic group under IRO care in terms of their chances of eventual resettlement abroad. ${ }^{64}$ There were many Poles in Turkey who sympathized with the former Polish and Yugoslav Governments in exile (e.g., consular and embassy staff members and personnel). Practically all these Poles were either refugees with Polish nationality or Polish origin but stateless persons.

\section{CONCLUSION}

It is important to emphasize the fact that, despite the ongoing war, relations between Poland and Turkey remained positive, with both sides expressing goodwill towards each other. Michał Sokolnicki, who was appointed Ambassador in 1936, remained in his post until 1946, who gave the lie to Nazi-Soviet claims that the Polish

59 AN, France, AJ 43/52, Letter for Sir Herbert Emerson director of Intergovernmental Committee on Refugees in London, Ankara, March 1, 1947, p. 1.

${ }^{60}$ AN, France, AJ 43/52, List of the Polish refugees in the tragic situation, Ankara, March 1, 1947, p. 1.

${ }_{61}$ There is no more information known about him.

62 BCA. 30.18.1.2 DCM/121.112.20

${ }_{63}$ AN, London, FO 371/72551, Documents from British Embassy in Ankara about Polish-Turkish Agreement, Ankara August 13, 1948, p. 2.

${ }_{64}$ AN, France, AJ 43/1065, Report to The Under Secretary of State for Foreign Affairs, the Foreign Office in London, June 21, 1949, p. 84. 
State had ceased to exist. One of the main routes through which volunteers could reach the Anders' Army passed through Turkish territory. It was also via Turkey that supplies of Polish gold were transported..$^{65}$ Poles hold a very special place in the history of the Ottoman Empire and later also the Republic of Turkey. Monuments have been built to Polish military commanders who served the Ottoman Empire and their deeds and exploits continue to be remembered today. But civilian Poles who came to Turkey during and after the Second World War have been treated differently by historians. Employed mostly as engineers, they helped expand and modernize Turkish industry and integrated well into Turkish society. Unfortunately, yet their legacy as key figures in the Republic of Turkey remains unknown.

On the other hand, for the most part Poles were unaware of Turkey's stance as a "friendly" neutral during the war. The Turkish government was pragmatic in its treatment of both sides and did not want to risk incurring the wrath of the Axis powers or, later, the Soviet Union. Nevertheless, whenever it could, it tried to be of assistance to Poles, facilitating the transport and transfer of soldiers and equipment, as well as the transit of people to Palestine. Turkish-Polish relations were disrupted by the raising of the Iron Curtain. The two countries found themselves in different camps. Despite this, however, the spirit of Polish-Turkish friendship survived and continues to survive - despite the passage of time.

\section{BIBLIOGRAPHY}

\section{Primary Sources}

Archives Nationales de France, Pierrefitte-sur-Seine, Archives of the I.R.O. - AJ 43. Başbakanlık Cumhuriyet Arşivi 30.18.1.2 Decisions of the Council of Ministers, 1920-1975. The National Archives in London, Foreign Office - FO 371.

The Polish Institute and Sikorski Museum in London, A.11.E, Ministry of Foreign Affairs; A.12., Staff of the Commander-in-Chief and the Ministry of Military Affairs, 1939-1948. T.C. Başbakanlık Devlet Arşivleri Genel Müdürlüğü BCA 030180102931027 [in:] Yoldaki

Elçi Osmanlıdan günümüze Türk-Leh ilişkileri / Poseł w drodze. Stosunki turecko-polskie od czasów osmańskich do dnia dzisiejszego, İstanbul 2014.

\section{Primary Sources Published}

Grammatica Turcia-Latina, İstanbul 1658.

Djelaleddine M., Turcs Anciens et Modernes, Constantinople 1869.

Sokolnicki M., Dziennik ankarski 1939-1942, vol. I, Londyn 1965.

Sokolnicki M., Dziennik ankarski 1943-1946, vol. II, Londyn 1974.

65600 lat kontaktów polsko-tureckich 1414-2014, katalog wystawy, Warszawa 2014, p. 143. 
Türkçe-Latince Sözlük, İstanbul 1658.

Ufki A., Местиа-i Saz ü Söz, İstanbul 1650.

\section{Literature}

600 lat kontaktów polsko-tureckich 1414-2014, katalog wystawy, Warszawa 2014.

Baş O.F., "THK Uçak Fabrikası ve Polonyalıların Rolü," Mühendis ve Makina 2014, no. 55, pp. 36-42.

Birbudak T.S., Akbaba B., "II. Dünya Savaşı Yıllarında Türkiye'de Bulunan Polonyalılar," Ankara Üniversitesi Türk Inkılâp Tarihi Enstitüsü Atatürk Yolu Dergisi 2018, no. 62.

Dopierała K., Adampol-Polonezköy. Z dziejów Polaków z Turcji, Poznań 1983.

Dopierała K., Emigracja polska w Turcji w XIX i XX wieku, Lublin 1988.

Kodal T., "Türk Arşiv Belgelerine Göre II. Dünya Savaşı (1939-1945) Yıllarında Türkiye Üzerinden Filistin'e Yahudi Göçleri," Atatürk Üniversitesi Atatürk Dergisi 2007, no. 5.

Kołodziejczyk D., "Komşuluktan Kardeşliğe: Osmanl1-Polonya ve Türkiye-Polonya Tarihi İlişkilerinden Birkaç Manzara" [in:] 600. Yılında Türkiye-Polonya İlişkileri Sempozyumu Bildirileri, ed. H. Topaktaş, Ankara 2014.

Lewis B., Narodziny nowoczesnej Turcji, Warszawa 1972.

Łątka J.S., Polacy w Turcji, Lublin 1980.

Odabaşı A., Mustafa Celaleddin Paşa ve Eski ve Yeni Türkler, İstanbul 2014.

Olszowska K., "The Protection Provided by International Refugee Organizations in Turkey in the Immediate Post-war Period," Zeszyty Naukowe Uniwersytetu Jagiellońskiego. Prace Historyczne 2019, no. 3, pp. 607-619.

Ortaögretim Tarih Ders Kitabı, MEB Yayınları, İstanbul 2018.

Ortaöğretim Tarih Ders Kitabı, Tuna Yayınları, İstanbul 2019.

Pawlina A., "Wojciech Bobowski (Ali Ufki) - Polak na osmańskim dworze" [in:] Wschód muzutmański w ujęciu interdyscyplinarnym. Ludzie - teksty - historia, eds. G. Czerwiński, A. Konopacki, Białystok 2017.

Sękowski P., "Activity of the International Community in Europe after the Second World War within the Scope of the International Refugee Organization as a Model of the Aid Action Towards Refugees," Securitologia 2017, no. 3.

Stachowski M., "Kowalski, Caferoğlu und die Universität Stambul," Türk Dilleri Araştırmaları 1998, no. 8.

Topaktaş H., "Polonezköy (Adampol) 1842-1922 - Kurulus, Tabiyet Meselesi, İmar Faaliyetleri ve Sosyal Hayat," Belleten 2015.

Turan Ş., Atatürk'ün Düşünce Yapısını Etkileyen Olaylar, Düşünürler, Kitaplar, Ankara 1999.

Unat K., "Atatürk Sonrası Türkiye” [in:] Başlangıcından Günümüze Türkiye Cumhuriyeti Tarihi, ed. T.F. Ertan, Ankara 2012.

“Üzerinden Filistin'e Yahudi Göçleri," Atatürk Üniversitesi Atatürk Dergisi 2007, no. 5.

Vasileva D., "Bulgarian Turkish Emigration and Return," International Migration Review, 1992, no. 26.

Ziółkowski P., Adampol (Polonezkioj) Osada Polska w Azji Mniejszej - Zapiski historyczne, Poznań 1929. 